\title{
ラインセンサスを通してみた京阪奈丘陵の鳥類と里地・ 里山の景観構造との関係
}

\section{Relationship between Bird Fauna Studied by Line Transect Counts and Structure of Satoyama-landscape on the Keihanna Hills}

\author{
中津 弘* 前中 久行* 夏原 由博* \\ Hiromu NAKATSU Hisayuki MAENAKA Yoshihiro NATUHARA
}

\begin{abstract}
Traditional rural landscapes, Satochi and Satoyama in Japan are important factors for conservation of biological diversity. We conducted line transect counts of birds and vegetation research on the Keihanna Hills from May 2001 to April 2002, to describe relative abundance of bird species and bird-habitat relationship in Satoyama and Satochi, and to offer materials for comparisons to similar studies. Through the counts we recorded a total of 10069 birds of 74 species. Dominant five species amounted approximately $60 \%$ of the total number of birds counted. The vegetation type with which the number of a bird species correlated changed depending on which species was being focused. The species richness did not correlate to the percentage of woodland area in the study sites. Species richness of breeding birds correlated with no vegetation type. Species richness of wintering birds correlated with percentage of grassland area, and numbers of landscape units in the study sites; this result suggested that human activities that created landscape mosaics were important for bird diversity.
\end{abstract}

Keywords: satochi/satoyama, birds, rare species, vegetation キーワード：里地・里山，鳥類，希少種，相観植生

\section{1.はじめに}

かつて薪炭林として利用された二次林や草地, ため池や水路を 含む農地, 集落加らな里地・里山には, 生物多様性保全の観点 から重要な二次的自然 ${ }^{1)}$ が存在し, 日本の生物相の中でも重要な

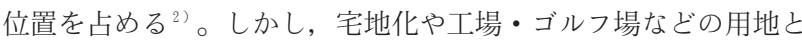
しての改変, 農地の耕作放棄や圃場整備, 二次林の管理放棄など から里地・里山は姿を変えつつある2 ${ }^{2,3)}$ 。

このような生息地の変化などから，二次的自然に生息する多く の鳥類種がレッドデータブックに希少種として掲載されてお $り^{4)}$ ，里地・里山に生息する鳥類について，個々の種や群集に之っ ての生息地の評価と同時に, 地域ごとの鳥類相の把握と定量的デー 夕の収集が重要な調查研究の課題といえる。個別の鳥類生息地の 特性については, 樹林地面積や樹木率(5),6), 樹林地の内部構造 ${ }^{7,8,8,99}$, 農地 ${ }^{10), 11}$, 都市環境での舗装率 ${ }^{12)}$ などの多くの研究が蓄積されて きたが，複数の生息地タイプによって形づくられる里地・里山の 鳥類之生息地の関わりを調べた研究は少ない。また, 里地・里山 の鳥類について, 経年的にあるいは他地域と比較する定量的なデー 夕あ不足している。

本研究では, ラインセンサスによって得られたデータから京阪 奈丘陵の里地・里山に打ける鳥類相之, 種ごとの個体数の相対的 な多さについて報告し, 個々の生息地夕イプの面積割合やモザイ ク構造といった，相観植生レベルでの生息地の特徵とそこに生息 する種数や個体数との関係のありようを記述し, 里地・里山の鳥 類生息地としての特性を議論する。また, 当該地域や他地域で行 われる，類似した調査研究に比較材料を提供する。

\section{2. 方法}

\section{(1) 調查地}

京阪奈丘陵は, 京都府・大阪府・奈良県の境界部分に広がる, 標高抢よそ数十 $\mathrm{m}$ から $350 \mathrm{~m}$ の丘陵地である。コナラQuercus serrta を主体とする二次林, 植林や竹林などからなる他の樹林
地, 山麓部分や平坦地などの集落, 水田などの農地, 草地が形成 されている。

調査では, 京阪奈丘陵に 4 つの調査ルートを設置した。すなわ ち，傍示－国見山（枚方市・交野市），穂谷（枚方市），尺治川一 くろんど園地 (交野市), 高山（生駒市・精華町）である（以下, それぞれ HK, HT, SK, TK と略す)。二次林, 農地, 草地, 集落は伝統的農村景観を形成する ${ }^{13)}$ から，集落が樹林地や農地， 草地之接している場合にはその境界から $100 \mathrm{~m}$ 以内の集落む景観 の要素と判断して調査範囲に含めルートを定めた。

\section{(2) 鳥類調査}

鳥類調査はラインセンサス法によって行った。2001 年 5 月か ら 2002 年 4 月にかけ，4つのルートそれぞれについて，繁殖期 （5月初旬から 8 月中旬）と越冬期（11月中旬加 2 月下旬）に 5 回ずつ, 春季と秋期に 3 回ずつ, 合計 16 回ずつ調査を行った。 晴天あるいは曇天の条件下で，午前 7 時から 10 時 30 分の間にお よそ時速 $2 \mathrm{~km}$ でルートを歩き, 観察半径 $25 \mathrm{~m}$ の範囲内に出現す る鳥類の種名，個体数を記録し，出現位置のマッピングを行った。 自治体発行の都市計画地図から 2500 分の 1 の調査ルート地図を 作成し，マッピングに利用した。鳥類の出現と植生の対応関係を 調べられるように，各ルートを $50 \mathrm{~m} \times 200 \mathrm{~m}$ の小区間 20 個（全 体で計 80 個）に区切った。観察には必要に応じて 7 倍の双眼鏡 を使用した。

\section{(3) 植生調查}

植生調査では, 1999 年 5 月に撮影された空中写真からの判読 と， 2001 年 7 月， 8 月と 2002 年 9 月， 10 月に現地で行った調査 をむとに，鳥類調查を行った範囲について 2500 分の 1 の相観植 生図を作成した。植生図の作成にあたっては直径 $10 \mathrm{~m}$ 以上の植 生を調查ルート地図に記入した。ここで扱う相観植生は, 樹林地, 草地, 農地, 開放水面, 裸地, 人工施設の 6 つである。

(4) 分析

出現鳥類と植生の関わりを調べるにあたっては，小区間ごとの

\footnotetext{
*大阪府立大学大学院農学生命科学研究科
} 
表 -1 出現鳥類リスト

\begin{tabular}{|c|c|c|c|c|c|c|c|c|c|c|c|}
\hline \multirow{3}{*}{ 科名 } & \multirow{3}{*}{ 種名 } & \multirow{3}{*}{ 学名 } & \multirow{2}{*}{\multicolumn{2}{|c|}{ HK }} & \multirow{2}{*}{\multicolumn{2}{|c|}{ HT }} & 下名 & & & & 全ルー \\
\hline & & & & & & & SI & & & & 卜 4 期 \\
\hline & & & 繁殖期 & 越冬期 & 繁殖期 & 越冬期 & 繁殖期 & 越冬期 & 繁殖期 走 & 越冬期 & 合計 \\
\hline カイツブリ & カイツブリ & Podiceps ruficollis & & & & & & & & 2 & 2 \\
\hline サギ & アマサギ & Bubulcus ibis & & & & & & & 2 & & 2 \\
\hline & ダイサギ & Egretta alba & & & & & & & 2 & & 2 \\
\hline & チュウサギ & Egretta intermedia & & & & & & & 3 & & 3 \\
\hline & コサギ & Egretta garzetta & & & & & & & 1 & & 1 \\
\hline & アオサギ & Ardea cinerea & & & 4 & 1 & 1 & 3 & 9 & 1 & 29 \\
\hline カモ & マガモ & Anas platyrhynchos & & & & & & & & 2 & 2 \\
\hline & カルガモ & Anas poecilorhyncha & & & & & 3 & & & & 3 \\
\hline タカ & オオタカ & Accipiter gentilis & & 1 & & & & & & 2 & 4 \\
\hline & ハイタカ & Accipiter nisus & & & & 1 & & & & 4 & 6 \\
\hline & ノスリ & Buteo buteo & & & & 3 & & 1 & & 1 & 7 \\
\hline & サシバ & Butastur indicus & & & & & & & & & 1 \\
\hline キジ & コジュケイ & Bambusicola thoracica & 3 & 6 & & 4 & 4 & 12 & & 13 & 53 \\
\hline & ヤマドリ & Phasianus soemmeringii & 1 & & & & & & & & 1 \\
\hline & キジ & Phasianus colchicus & & & 2 & 6 & & & 8 & 5 & 31 \\
\hline チドリ & コチドリ & Charadrius dubius & & & & & & & & & 2 \\
\hline シギ & ヤマシギ & Scolopax rusticola & & & & & & & & 1 & 1 \\
\hline ハト & キジバト & Streptopelia orientalis & 11 & 3 & 24 & 23 & 1 & 2 & 7 & 15 & 146 \\
\hline & アオバト & Sphenurus sieboldii & & 1 & & & 1 & & & & 3 \\
\hline カッコウ & ホトトギス & Cuculus poliocephalus & 1 & & 1 & & & & & & 2 \\
\hline アマツバメ & ハリオアマツバメ & Chaetura caudacuta & & & & & & & & & 3 \\
\hline カワセミ & カワセミ & Alcedo atthis & & & & & 3 & & & & 4 \\
\hline キツツキ & アオゲラ & Picus awokera & & 1 & 1 & & 3 & & & & 7 \\
\hline & アカゲラ & Dendrocopos major & & & & 3 & & 1 & & & 7 \\
\hline & コゲラ & Dendrocopos kizuki & 19 & 20 & 8 & 9 & 15 & 22 & 2 & 6 & 152 \\
\hline ヒバリ & ヒバリ & Alauda arvensis & & & & & & & & & 1 \\
\hline ツバメ & ツバメ & Hirundo rustica & 33 & & 107 & & 13 & & 96 & & 290 \\
\hline & コシアカツバメ & Hirundo daurica & & & & & & & 20 & & 47 \\
\hline & イワツバメ & Delichon urbica & & & & & 6 & & & & 6 \\
\hline セキレイ & キセキレイ & Motacilla cinerea & & & 7 & 1 & 8 & 6 & & & 47 \\
\hline & ハクセキレイ & Motacilla alba & & & & 2 & & & & 3 & 5 \\
\hline & $\begin{array}{l}\text { セグロセキレイ } \\
\text { ビンズイ }\end{array}$ & Motacilla grandis & 2 & 1 & & & & 7 & 11 & 4 & 36 \\
\hline ヒヨドリ & $\begin{array}{l}\text { ビンズイ } \\
\text { ヒヨドリ }\end{array}$ & $\begin{array}{l}\text { Anthus hodgsoni } \\
\text { Hypsipetes amaurotis }\end{array}$ & 45 & 191 & 71 & $\begin{array}{r}6 \\
154\end{array}$ & $\begin{array}{r}1 \\
61\end{array}$ & $\begin{array}{r}7 \\
176\end{array}$ & 65 & 126 & $\begin{array}{r}22 \\
1485\end{array}$ \\
\hline モズ & モズ & Lanius bucephalus & & $\begin{array}{r}191 \\
5\end{array}$ & 1 & $\begin{array}{r}154 \\
8\end{array}$ & 01 & & 3 & $\begin{array}{r}126 \\
11\end{array}$ & $\begin{array}{r}1403 \\
76\end{array}$ \\
\hline レンジャク & ヒレンジャク & Bombycilla japonica & & & & & 30 & & & & 30 \\
\hline ミソサザイ & ミソサザイ & Troglodytes troglodytes & & 2 & & 1 & & 3 & & 1 & 10 \\
\hline ヒタキ & コマドリ & Erithacus akahige & 1 & & & & & & & & 3 \\
\hline & ルリビタキ & Tarsiger cyanurus & & 26 & & 12 & & 28 & & 16 & 87 \\
\hline & ジョウビタキ & Phoenicurus auroreus & & 3 & & 12 & & 7 & & 7 & 38 \\
\hline & トラツグミ & Turdus dauma & & & & 2 & & & & & 3 \\
\hline & クロツグミ & Turdus cardis & & & & & 1 & & & & 1 \\
\hline & シロハラ & Turdus pallidus & & 34 & & 24 & & 64 & & 10 & 181 \\
\hline & ツグミ & Turdus naumanni & & 20 & & 160 & & 77 & & 236 & 525 \\
\hline & ヤブサメ & Cettia squameiceps & 13 & & 4 & & 9 & & & & 54 \\
\hline & ウグイス & Cettia diphone & 15 & 32 & 19 & 27 & 21 & 26 & 22 & 33 & 349 \\
\hline & $\begin{array}{l}\text { メボソムシクイ } \\
\text { エゾムシクイ }\end{array}$ & $\begin{array}{l}\text { Phylloscopus borealis } \\
\text { Phylloscopus tenellipes }\end{array}$ & & & & & & & & & 2 \\
\hline & センダイムシクイ & Phylloscopus occipitalis & & & & & 2 & & 2 & & 9 \\
\hline & キビタキ & Ficedula zanthopygia & 2 & & & & & & & & 7 \\
\hline & オオルリ & Cyanoptila cyanomelana & & & & & 6 & & & & 16 \\
\hline & サンコウチョウ & Terpsiphone atrocaudata & & & & & & & 1 & & 1 \\
\hline エナガ & エナガ & Aegithalos caudatus & 51 & 75 & 22 & 87 & 30 & 111 & 1 & 6 & 757 \\
\hline シジュウカラ & コガラ & Parus montanus & & & & & & & & & 2 \\
\hline & ヤマガラ & Parus varius & 20 & 28 & 12 & 6 & 19 & 27 & 5 & 1 & 205 \\
\hline & シジュウカラ & Parus major & 27 & 26 & 19 & 16 & 32 & 40 & 10 & 5 & 275 \\
\hline メジロ & メジロ & Zosterops japonica & 53 & 78 & 42 & 82 & 82 & 114 & 9 & 46 & 857 \\
\hline ホオジロ & ホオジロ & Emberiza cioides & 24 & 22 & 21 & 60 & 19 & 34 & 36 & 99 & 495 \\
\hline & カシラダカ & Emberiza rustica & & 15 & & 33 & & 1 & & 155 & 251 \\
\hline & ミヤマホオジロ & Emberiza elegans & & 1 & & & & & & 1 & 2 \\
\hline & アオジ & Emberiza spodocephalla & & 43 & & 88 & & 23 & & 57 & 310 \\
\hline アトリ & アトリ & Fringilla montifringilla & & 2 & & & & & & & 2 \\
\hline & カワラヒワ & Carduelis sinica & 7 & 5 & 11 & 2 & 1 & 7 & 24 & 26 & 103 \\
\hline & マヒワ & Cauduelis spinus & & & & 1 & & 47 & & & 71 \\
\hline & ベニマシコ & Uragus sibiricus & & 3 & & 4 & & & & 6 & 15 \\
\hline & ウソ & Pyrrhula pyrrhula & & & & 1 & & & & & 1 \\
\hline & イカル & Eophona personata & & & & & 1 & & & & 25 \\
\hline & シメ & Coccothraustes coccothraustes & & 21 & & 26 & & 8 & & 12 & 107 \\
\hline ハタオリドリ & ニュウナイスズメ & Passer rutilans & & & & & & & & & 60 \\
\hline & スズメ & Passer montanus & 99 & 17 & 369 & 335 & 63 & 3 & 225 & 408 & 2241 \\
\hline ムクドリ & ムクドリ & Sturnus cineraceus & & & & & & & 9 & 22 & 38 \\
\hline カラス & カケス & Garrulus glandarius & & 2 & & & & & 1 & & 5 \\
\hline & ハシボソガラス & Corvus corone & 2 & 3 & 5 & & & & 1 & 8 & 30 \\
\hline & ハシブトガラス & Covus macrorhynchos & 34 & 26 & 43 & 79 & 16 & 13 & 18 & 20 & 409 \\
\hline & & 合計種数 & 21 & 31 & 21 & 34 & 28 & 27 & 27 & 36 & 74 \\
\hline & & 合計個体数 & 463 & 713 & 793 & 1279 & 452 & 863 & 593 & 1371 & 10069 \\
\hline
\end{tabular}

注：4つのルートごとに繁殖期・越冬期の種ごとの個体数を記述し、全ルート合計の通年 4 期での個体数をあわせて示した。 


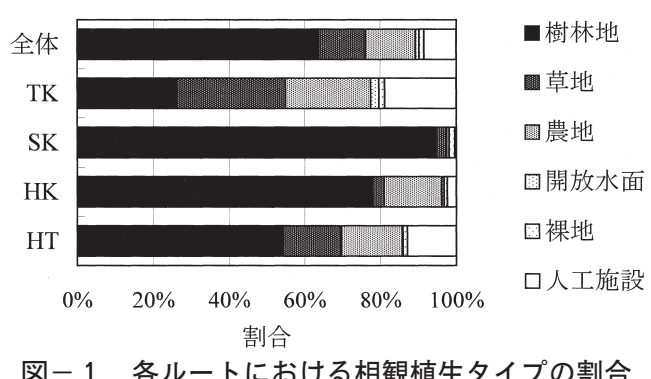

図ー 1 各ルートにおける相観植生タイプの割合

表 -3 繁殖期・越冬期の合計出現種数・個体数と植生タイプの 割合・モザイク構造の相関

\begin{tabular}{|c|c|c|c|c|c|c|}
\hline & 樹林地 & 草地 & 農地 & $\begin{array}{c}\text { 人工施 } \\
\text { 設 }\end{array}$ & $\begin{array}{l}\text { モザイ } \\
\text { ク種数 }\end{array}$ & $\begin{array}{l}\text { モザイ } \\
\text { ク個数 }\end{array}$ \\
\hline \multicolumn{7}{|l|}{ 繁殖期 } \\
\hline 種数 & 0.140 & 0.056 & -0.128 & -0.157 & 0.078 & 0.053 \\
\hline 個体数 & -0.181 & 0.054 & 0.025 & $\underline{0.229}$ & 0.404 & 0.377 \\
\hline \multicolumn{7}{|l|}{ 越冬期 } \\
\hline 種数 & -0.062 & 0.228 & -0.047 & -0.059 & $\underline{0.247}$ & $\underline{0.253}$ \\
\hline 個体数 & -0.390 & 0.032 & 0.118 & $\underline{0.553}$ & $\underline{0.415}$ & 0.483 \\
\hline
\end{tabular}

表一４スズメを除いた繁殖期・越冬期の合計出現個体数と植生 タイプの割合・モザイク構造の相関

\begin{tabular}{|c|c|c|c|c|c|c|}
\hline & 樹林地 & 草地 & 農地 & $\begin{array}{c}\text { 人工施 } \\
\text { 設 }\end{array}$ & $\begin{array}{l}\text { モザイ } \\
\text { ク種数 }\end{array}$ & $\begin{array}{l}\text { モザイ } \\
\text { ク個数 }\end{array}$ \\
\hline $\begin{array}{l}\text { 繁殖期 } \\
\text { 越冬期 }\end{array}$ & 0.054 & -0.007 & -0.218 & 0.063 & 0.197 & 0.084 \\
\hline 越冬期 & $\frac{-0.224}{\text { 有音な }}$ & $\begin{array}{r}0.048 \\
\text { 関係数 }\end{array}$ & $\begin{array}{r}0.053 \\
\text { は下線 }\end{array}$ & $\frac{0.309}{\text { Dtt }}$ & $\underline{0.284}$ & $\underline{0.285}$ \\
\hline
\end{tabular}

各相観植生タイプの面積割合や植生モザイク構造を説明变数, 小 区間ごとの出現種数・個体数を従属変数とし, 相関係数を計算し た。モザイク構造は, 小区間内の異質な植生で形づくられるモザ イクの種数と個数の 2 つを扱った。調査範囲全体に占める割合が $5 \%$ 以上の植生タイプを説明変数として検討した。分析上の仮定 は，ある植生タイプが鳥類生息に適した，あるいは不適な場合， その面積割合が出現種数や個体数之有意な相関を示す, 同様にモ ザイク構造が鳥類生息に適した，あるいは不適な場合にはモザイ クの種数や個数が出現種数や個体数之有意な相関を示す, という あのである。なお, 今回の調査範囲では樹林地以外の植生は連続 的に変化し, 樹林地以外の単一の植生タイプが 100\%を占める小 区間はなかったため，樹林地とその他を比べる以外には，植生夕 イプ間での出現傾向の比較や検定は行わなかった。

\section{3. 結果}

\section{(1) 植生調査}

4 ルート全体の植生タイプ割合は, 大きい順に，樹林地 $63.7 \%$ (うち落葉広葉樹林約 70\%), 農地 13.4\%（うち水田約 75\%), 草地 $12.3 \%$, 人工施設 $8.48 \%$, 裸地 $1.25 \%$, 開放水面 $0.93 \%$ で あった（図-1)。モザイク種数・個数は, 樹林地面積割合との 間に有意な負の相関（それぞれ $-0.696,-0.763 。 p<0.05$ ), 農 地・草地・人工施設の面積割合之の間にいずれも有意な正の相関 （それぞれ $0.406 ・ 0.479,0.366 ・ 0.451,0.303 ・ 0.342 。 p<0.05$ ) を示した。

\section{(2) 鳥類調査}

(i ) 鳥類相と個体数の相対的な多さ

調査の結果, 繁殖期に 44 種 2301 羽, 越冬期に 46 種 4226 羽, 通年で合計 74 種 10069 羽が観察された（表 1 )。 $4 \mathrm{~km}$ のつのルー 卜を 1 回歩いて観察される種数の平均 $\pm \mathrm{SD}$ は, 繁殖期で $15.4 \pm$ 2.56, 越冬期で $21.2 \pm 3.05$ であり, 同じく個体数の平均 $\pm \mathrm{SD}$ は, 繁殖期で $115 \pm 44.1$, 越冬期で $211 \pm 71.9$ であった。繁殖期と越
表-2 繁殖期・越冬期の種ごとの出現個体数と相関植生タイプ の割合・モザイク構造の相関

繁殖期

\begin{tabular}{|c|c|c|c|c|c|c|}
\hline 種名 & 樹林地 & 草地 & 農地 & $\begin{array}{c}\text { 人工施 } \\
\text { 設 }\end{array}$ & $\begin{array}{l}\text { モザイ } \\
\text { ク種数 }\end{array}$ & $\begin{array}{l}\text { モザイ } \\
\text { ク個数 }\end{array}$ \\
\hline スズメ & -0.277 & 0.076 & 0.188 & 0.257 & 0.367 & $\underline{0.438}$ \\
\hline ツバメ & -0.345 & 0.142 & -0.056 & 0.492 & 0.349 & 0.339 \\
\hline ヒヨドリ & 0.005 & 0.111 & -0.148 & 0.038 & 0.010 & 0.087 \\
\hline メジロ & 0.334 & -0.177 & -0.220 & -0.186 & -0.214 & -0.257 \\
\hline ハシブトガラス & -0.106 & -0.003 & 0.136 & 0.018 & $\underline{0.240}$ & $\underline{0.222}$ \\
\hline エナガ & $\underline{0.311}$ & -0.167 & -0.232 & -0.186 & -0.162 & -0.247 \\
\hline ホオジロ & $-\overline{0.063}$ & $\underline{0.253}$ & 0.040 & -0.195 & 0.083 & 0.074 \\
\hline シジュウカラ & $\underline{0.224}$ & $-\overline{-0.181}$ & -0.202 & 0.091 & 0.051 & -0.108 \\
\hline ウグイス & 0.106 & 0.193 & -0.121 & $\underline{-0.250}$ & 0.024 & 0.007 \\
\hline ヤマガラ & $\underline{0.366}$ & -0.142 & $\underline{-0.330}$ & $\overline{-0.212}$ & -0.150 & -0.230 \\
\hline コゲラ & 0.313 & $\underline{-0.250}$ & -0.152 & -0.149 & -0.163 & -0.248 \\
\hline カワラヒワ & $-\overline{0.342}$ & 0.205 & $\underline{0.272}$ & 0.163 & 0.196 & 0.136 \\
\hline キジバト & -0.112 & -0.114 & $\overline{0.070}$ & $\underline{0.269}$ & 0.183 & $\underline{0.222}$ \\
\hline ヤブサメ & $\underline{0.377}$ & $\underline{-0.228}$ & $\underline{-0.232}$ & $-\overline{-0.165}$ & $\underline{-0.336}$ & $-\overline{0.353}$ \\
\hline コシアカツ, & $-\overline{0.285}$ & $\overline{0.004}$ & $\overline{-0.003}$ & $\underline{0.515}$ & 0.178 & 0.217 \\
\hline
\end{tabular}
個体が観察されたヒレンジャクは除いた。

越冬期

\begin{tabular}{|c|c|c|c|c|c|c|}
\hline 種名 & 樹林地 & 草地 & 農地 & $\begin{array}{c}\text { 人工施 } \\
\text { 設 }\end{array}$ & $\begin{array}{l}\text { モザイ } \\
\text { ク種数 }\end{array}$ & $\begin{array}{l}\text { モザイ } \\
\text { ク個数 }\end{array}$ \\
\hline スズメ & -0.406 & 0.004 & 0.137 & 0.583 & 0.387 & $\underline{0.495}$ \\
\hline ヒヨドリ & 0.035 & $\underline{-0.228}$ & 0.201 & $\overline{0.142}$ & $\overline{0.074}$ & 0.071 \\
\hline ツグミ & -0.368 & $\overline{-0.046}$ & 0.068 & $\underline{0.645}$ & 0.213 & 0.229 \\
\hline メジロ & 0.307 & -0.302 & -0.177 & $-\overline{0.029}$ & -0.270 & -0.246 \\
\hline エナガ & 0.356 & -0.180 & -0.193 & -0.212 & -0.256 & -0.259 \\
\hline カシラダカ & $-\overline{0.171}$ & 0.289 & 0.096 & -0.093 & 0.259 & 0.251 \\
\hline ホオジロ & $\underline{-0.518}$ & $\underline{0.482}$ & $\underline{0.404}$ & -0.119 & $\overline{0.502}$ & 0.497 \\
\hline アオジ & -0.037 & $\underline{0.412}$ & -0.197 & -0.106 & 0.089 & 0.125 \\
\hline ハシブトガラス & -0.113 & -0.028 & -0.007 & 0.207 & $\underline{0.319}$ & $\underline{0.339}$ \\
\hline シロハラ & $\underline{0.343}$ & -0.214 & -0.175 & -0.180 & $\underline{-0.253}$ & $-\overline{0.324}$ \\
\hline ウグイス & 0.068 & 0.104 & -0.015 & -0.143 & $\overline{-0.044}$ & $\overline{0.043}$ \\
\hline シジュウカラ & $\underline{0.442}$ & -0.188 & -0.377 & -0.215 & -0.299 & -0.338 \\
\hline ルリビタキ & 0.281 & -0.111 & -0.117 & -0.253 & -0.210 & -0.265 \\
\hline シメ & -0.207 & -0.005 & $\underline{0.275}$ & 0.106 & 0.187 & 0.120 \\
\hline ヤマガラ & $\underline{0.317}$ & -0.348 & -0.304 & -0.188 & 0.056 & -0.221 \\
\hline コゲラ & 0.201 & -0.247 & -0.218 & -0.072 & 0.105 & -0.033 \\
\hline マヒワ & 0.131 & -0.083 & -0.110 & -0.072 & -0.079 & -0.105 \\
\hline キジバト & -0.324 & $\underline{0.225}$ & 0.156 & $\underline{0.226}$ & $\underline{0.314}$ & $\underline{0.413}$ \\
\hline カワラヒワ & -0.120 & $\overline{0.054}$ & -0.055 & $\overline{0.241}$ & $\overline{0.107}$ & 0.187 \\
\hline コジュケイ & 0.039 & 0.073 & -0.029 & $-\overline{0.127}$ & 0.000 & -0.050 \\
\hline ジョウビタキ & -0.263 & $\underline{0.267}$ & 0.177 & -0.217 & 0.172 & 0.075 \\
\hline モズ & -0.319 & 0.216 & 0.189 & -0.006 & 0.148 & 0.050 \\
\hline
\end{tabular}

※個体数が多いものから順に示した。また、2つの小区間で全ての 個体が観察されたムクドリは除いた。

冬期の観察を比較すると，種数は SK を除く 3 ルートで越冬期に より多く，個体数は全てのルートで越冬期に多くなった（表一 1 )。 繁殖期の個体数上位 5 種（スズメ・ツバメ・ヒヨドリ・メジロ・ 八シブトガラス, 計 1544 羽) は全体の $67.1 \%$ を占め, 越冬期の 個体数上位 5 種（スズメ・ヒヨドリ・ッグミ・メジロ・エナガ, 計 2502 羽）は全体の $59.2 \%$ であった。また，スズメの個体数は 繁殖期に 756 羽で全体の $32.9 \%$, 越冬期に 763 羽で $18.2 \%$ を占 めた。

繁殖期の観察種のうち, 14 種 36 羽 ${ }^{14)}$ が国 ${ }^{15)}$ や大阪府 ${ }^{16)}$ ，京都 府 $^{17)}$, 近畿版 ${ }^{4)}$ のレッドデータブック ${ }^{18)}$ (以下，レッドデータブッ ク類）の指定を受けており，合計個体数は全体の $1.56 \%$ 占め るにすぎなかったが，種構成では全体の $31.8 \%$ であった。また， 越冬期に観察された鳥類では，15 種 209 羽がレッドデータブッ ク類の指定を受けて抢り，全体の個体数の $4.95 \%$, 種構成では 全体の $32.6 \%$ であった。種ごとの観察個体数を 80 羽ごとに区切っ て 10 階級に分けると, 繁殖期・越冬期之も最も出現個体数が少 ない階級（1-80 羽）で最も種数が多かった（繁殖期 36 種, 越 冬期 33 種)。

(ii) 鳥類と植生の関わり

繁殖期・越冬期のそれぞれで 20 羽以上が出現した種（繁殖期 15 種 2115 羽, 越冬期 22 種 4026 羽）についての，小区間ごとの 
出現個体数之植生タイプの面積割合・モザイク構造との相関は, 種によって異なった（表一 2)。個々の種の出現個体数之有意な $(p<0.05)$ 正の相関が得られたものは, 樹林地の面積割合（繁殖 期・越冬期のシジュウカラ・エナガ・メジロ・ヤマガラなど), 草地の面積割合 (繁殖期・越冬期のホオジロ, 越冬期のカシラダ カ・アオジなど), 人工施設の面積割合 (繁殖期・越冬期のスズ メ, 繁殖期のッバメ, 越冬期のッグミなど), モザイクの種数・ 個数 (繁殖期・越冬期のスズメ・ハシブトガラス, 繁殖期のッバ メなど）があり, 有意な負の相関が得られたものは, 樹林地の面 積割合（繁殖期・越冬期のスズメ，繁殖期のッバメ，越冬期のッ グミなど), モザイク構造（越冬期にモザイクの種数・個数と相 関を示したシジュウカラ, 繁殖期に個数と相関を示し, 越冬期に 種数・個数と相関を示したメジロ・エナガ, 繁殖期・越冬期の個 数と相関を示したヤマガラなど）などであった。

繁殖期の合計種数・個体数と植生の関わりでは (表-3), 出 現個体数と, 人工施設の割合, モザイクの個数・種数との間で有 意な正の相関が得られた $(p<0.05)$ 。越冬期の出現種数・個体数 之植生の関わりでは, 出現個体数之樹林地面積割合の間で有意な 負の相関が, 出現個体数と, 人工施設, モザイクの個数・種数の 間で有意な正の相関が得られ $(p<0.05)$, 出現種数とモザイクの 個数・種数の間にも有意な正の相関が得られた $(p<0.05)$ 。樹林 地が 100\%を占める小区間（21 個）とその他の小区間（59 個） では, 平均出現種数が異なり, 繁殖期にはそれぞれ 6.95 小区間・7.92 2 2.42/小区間, 越冬期には $8.32 \pm 3.06$ /小区間・11. $1 \pm 2.73$ /小区間であった。樹林地が $100 \%$ の 小間とその他の小 区間の出現種数について U 検定を行うと, 繁殖期には有意差は なかったが $(\mathrm{Z}=1.11, p=0.268)$, 越冬期に有意差が認められ, 樹 林地が $100 \%$ の 小間で種数が少なかった（Z=3.51， $p=0.0004 ） 。$

繁殖期の全種合計の出現個体数からスズメを除くと, 合計出現 個体数之有意な相関を示す植生タイプやモザイク構造はなかった (表一 4 )。越冬期の合計出現個体数からスズメを除くと, 合計出 現個体数と有意な負の相関を示すのは樹林地, 有意な正の相関を 示すのは人工施設，モザイクの個数・種数であった $(p<0.05)$ 。

\section{4. 考察}

最む出現個体数の少ない階級に最む多くの種が属していたこと から, これらの種の観察機会は少なく, 種の生態や生息地の選択 など基礎的な情報収集は比較的困難な状況といえる。レッドデー タブック類に記載される希少種においても, 個体数は少ないが, 種組成では地域の鳥類の多様性に之って重要であると確認された。

大阪府内の土地利用と, そこで繁殖する鳥類の関係を調べた Natuhara and Imai ${ }^{19)}$ は, 鳥類によって, 連続した森林や分断 された森林, 農地など, 相関を示す生息地タイプが異なることを 報告している。今回の調查でも, 樹林地, 草地, 農地, 集落など 異なる環境に生息する個々の種のニーズが表一 2 に示したように 交錯して抢り，モザイク構造を利用する種むあることから，単一 の植生が多くの種の生息地になる傾向が得られなかったと考えら れる。この調査結果は, 平野ら ${ }^{6)}$ や黒沢 ${ }^{12)}$ の結果とは異なった。 平野らは, 宇都宮市などの都市部から郊外の樹林地にかけて調査 し, 繁殖期・越冬期とも樹林地率が増加するに従って生息する鳥 類の種数が増えることを報告している。黒沢は, 人口密度が高く 緑地率の小さい, 東京都内の都市部での調査から, 舗装率（舗装 抢よび建物で覆われている面積の割合）が大きくなると, 繁殖期 に出現する種数が小さくなると報告している。今回の調査で人工 施設割合が高いほど出現種数が減少するという結果が得られなかっ たのは，樹林地・草地・農地などの生息地と接した里地の集落な
どからなる人工施設には, 点在・隣接する他の生息地や資源をむ 利用して生息する種（スズメ，ッバメ，コシアカッバメ，キジバ ト, ツグミ，カワラヒワなど）が少なからずあったためと考えら れる。

$50 \times 200 \mathrm{~m}$ の小間で認められるスケールのモザイク構造は複 数の生息地を利用する種や生息地の辺縁部を利用する種の生活に 向いており，過度に小片化しなければ違った生息地を利用する複 数の種が同じ区間に生息し得ると推測できる。

個別の生息地の面積や割合を調べると鳥類生息にとって適不適 があると知られており, 今回の調査でもシジュウカラ, エナガ, メジロなどにとっては樹林地割合の重要性が指摘される。しかし， 鳥類相全般について里地・里山を相観植生レベルでみた場合, 単 一の大きな生息地よりあ, 隣接して存在する異質な環境やモザイ ク構造が, 調査地域の里地・里山で特に越冬期の鳥類生息地とし て重要な役割を果たしている可能性がある。里地・里山のモザイ クの形成は, 農地や, 特に休耕田などの一時的な草地, 人工施設 などによってもたらされ，人為の影響によるところが大きい。モ ザイク構造自体と人為的管理の重要性が示唆される。

謝辞

本研究にあたり, 大阪府立大学名誉教授の佐藤治雄氏には有用 なアドバイスを頂いた。厚く扔礼申し上げる。

\section{補注及び引用文献}

1）既谷いづみ・矢原徹一（1996）：保全生態学入門：文一総合出版, $270 \mathrm{pp}$

2 ) 田端英雄編（1997）：里山の自然：保育社, 199pp.

3 ）上杉哲郎（1998）：自然環境保全の場としての里山：ランドスケープ 研究 61(4), 284-286

4 ）山岸哲監修（2002）：近畿地区・鳥類レッドデータブック：京都大学 学術出版会, $225 \mathrm{pp}$

5 ）樋口広芳・塚本洋三・花輪伸一・武田宗也（1982）：森林面積と鳥の 種数との関係: Strix 1，70-79

6 ）平野敏明・遠藤孝一・仁平康介・金原啓一・樋口広芳（1985）: 宇都 宮市に抢ける樹木率と鳥の種数との関係：Strix 4, 33-42

7 ) 由井正敏 (1988)：森に棲む野鳥の生態学：創文, $237 \mathrm{pp}$

8 ）一八瀬友博・加藤和弘（1996）：埼玉県所沢市の孤立樹林地における 越冬期の鳥類分布と植生構造との関係について：ランドスケープ研究 59(5), 73-76

9 ) 一八瀬友博・加藤和弘 (2003) : 都市域の小規模樹林地と都市公園に おける越冬期の鳥類分布に影響する要因：ランドスケープ研究 66(5), 631-634

10) Lane S. J. and M. Fujioka (1998): The impact of changes in irrigation practices on the distribution of foraging egrets and herons in the rice fields of central Japan: Biological Conservation 83, 221-230

11) Fujioka, M., J. W. Armacost Jr., H. Yoshida, and T. Maeda (2001): Value of fallow farmlands as summer habitats for waterbirds in a Japanese rural area : Ecological Research 16, 555567

12）黑沢令子（1994）：東京における鳥類相の環境要因としての舗装率： Strix 13, 155-164

13）武内和彦・熟谷いづみ・恒川篤史編（2001）：里山の環境学：東海大 学出版会, $257 \mathrm{pp}$

14）近畿地区の $\mathrm{RDB}$ 指定で「繁殖個体群」「越冬個体群」の指定を受け たものが，それぞれ繁殖期，越冬期に観察された場合，機械的に含め た。

15）環境省編（2002）：改訂・日本の絶滅の捄それのある野生生物 レッ ドデータブック 2 鳥類：財団法人自然環境研究センター, $278 \mathrm{pp}$

16）大阪府（2000）: 大阪府に抢ける保護上重要な野生生物 大阪府レッ ドデータブック：大阪府, $442 \mathrm{pp}$

17）京都府 (2002)：京都府レッドデータブック 2002 : 京都府, 935pp

18）奈良県はレッドデータブックを発行していない。

19) Natuhara and Imai (1996): Spatial structure of avifauna along urban-rural gradients : Ecological Research 11, 1-9 